\title{
Serovars of Salmonella spp Isolated from Broiler Chickens and Commercial Breeders in Diverse Regions in Brazil from July 1997 to December 2004
}

Author(s)
Kanashiro AMI
Stoppa GFZ
Cardoso ALSP
Tessari ENC
Castro AGM
Centro Avançado de Pesquisa Tecnológica do
Agronegócio Avícola, Instituto Biológico, São
Paulo.

\section{Mail Address}

Ana Maria lba Kanashiro

Rua Bezerra Paes, 2278

13.690-000. Descalvado, SP, Brazil.

E-mail: anaiba@biologico.sp.gov.br

\section{Keywords}

Poultry, Salmonella, serovars.

\section{Acknowledgements}

The authors thank Dra. Eliane Falavina dos Reis, Laboratório de Enterobactérias, FIOCRUZ, $\mathrm{RJ}$, for serotyping the Salmonella isolates.
Arrived: june / 2005

Approved: august / 2005

\section{ABSTRACT}

Avian salmonellosis is a worldwide problem to the poultry industry, from the point of view of animal health and public health as well. The aim of the present study was to survey the most common Salmonella serovars in commercial breeders or broiler flocks from several regions in Brazil. The results of the present study indicated a high incidence of $S$ enterica subspecies enterica serovar Enteritidis in breeders (57.5\%) and broilers flocks (84.0\%). The importance of these findings lies in the fact that $\mathrm{S}$. Enteritidis has become the most frequent serovar responsible for foodborne outbreaks and sporadic cases of salmonellosis in humans.

\section{INTRODUCTION}

Avian salmonella infections are distinguished between pullorum disease (Salmonella enterica subspecies enterica serovar Pullorum - S. Pullorum), fowl typoid ( $S$. enterica subspecies enterica serovar Gallinarum) and paratyphoid (other salmonellas) (Berchieri Jr, 2000). The intensive large scale production adopted by the poultry industry favors the introduction, establishment, maintenance and dissemination of paratyphoid salmonellas. Therefore, paratyphoid infections currently present a problem to poultry farmers (Berchieri Jr, 2000) and constitute a hindrance to the poultry industry worldwide from the point of view of animal health and also as a consequence of the involvement of poultry products in considerable problems to public health (Barrow, 1999). In Brazil, outbreaks caused by $S$. Enteritidis (SE) occurred after cases in Europe, United States of America and Japan (Tavechio et al., 1996; Fernandes et al., 2003), probably due to the importation of grandparents from these regions (Zancan et al., 2000). Nevertheless, information on the actual condition of avian paratyphoid in Brazil is scarce. Many control measures have been established, from the elimination of infected flocks and vaccination to the extensive use of drugs in breeders and one-dayold progenies (Nepomuceno, 1997). This study presents a profile of the serovars of Salmonella spp most commonly isolated from flocks of commercial breeders and broilers in different regions in Brazil, from July 1997 to December 2004.

\section{MATERIAL AND METHODS}

\section{Samples}

Salmonella spp was investigated in samples received from diverse poultry industries located in different regions in Brazil, between July 1997 and December 2004. The samples were collected in farms of broilers and commercial breeders in the following Brazilian States: Bahia, Ceará, Goiás, Paraná, Mato Grosso, Mato Grosso do Sul, Santa Catarina and São Paulo.Various sample types were submitted to analysis: cloacal 
Kanashiro AMI, Stoppa GFZ, Cardoso ALSP, Tessari ENC, Castro AGM swabs, dragging swabs, swabs from chick boxes, pipped eggs, live or dead birds, feces and meconium.

\section{Bacteriology}

Bacteriological procedures to isolate Salmonella spp were performed according to Brasil (1995). Samples of swabs, feces and meconium were incubated in buffered peptone water at $37^{\circ} \mathrm{C}$ for 18 to 24 hours and aliquots were transferred to tetrathionate and selenite enrichment broths. The samples from pipped eggs and birds (live or dead) were directly incubated in selective enrichment broths and also in Brain Heart Infusion broth. After incubation at $41^{\circ} \mathrm{C}$ for 24 hours in a shaking water bath, a loopful of each sample was streaked onto XLT-4 and MacConkey agar plates and incubated at $37^{\circ} \mathrm{C}$ for 24 hours. Suspected colonies were transferred to triple sugar iron (TSI), lysine iron agar (LIA), urea and SIM medium (sulphide, indole, motility). Suspected Salmonella spp colonies were serotyped at a reference centre (Fundação Instituto Oswaldo Cruz). All media used in the study were purchased from Difco Laboratories.

\section{RESULTS}

Three hundred and ninety-one samples from breeders and 94 samples from broilers were positive for Salmonella spp. The eight most frequently isolated serovars and their respective sources are shown in Table 1. The results evidenced that SE is the most frequent serovar in breeders (57.5\%) and broilers chickens (84\%). The second most predominant serovar was S. Heidelberg (SH) in breeders (22.8\%) and S. I 9, 12: - : - in broilers chickens (9.6\%).

\begin{tabular}{|c|c|c|c|c|}
\hline \multirow{3}{*}{ Serovars } & \multicolumn{4}{|c|}{ Source } \\
\hline & \multicolumn{2}{|c|}{ Breeders } & \multicolumn{2}{|c|}{ Broilers } \\
\hline & $N^{*}$ & $\%$ & $\mathbf{N}$ & $\%$ \\
\hline S. Enteritidis & 225 & 57.5 & 79 & 84.0 \\
\hline S. Heidelberg & 89 & 22.8 & 0 & 0 \\
\hline S. Kentucky & 17 & 4.3 & 0 & 0 \\
\hline S.I 9,12: - : - & 10 & 2.6 & 9 & 9.6 \\
\hline S. Infantis & 8 & 2.1 & 0 & 0 \\
\hline S. Mbandaka & 7 & 1.8 & 0 & 0 \\
\hline S. Typhimurium & 5 & 1.3 & 2 & 2.1 \\
\hline S. Senftenberg & 6 & 1.5 & 1 & 1.1 \\
\hline Others & 24 & 6.1 & 3 & 3.2 \\
\hline Total & 391 & 100.0 & 94 & 100.0 \\
\hline
\end{tabular}

* number of samples.
Serovars of Salmonella spp Isolated from Broiler Chickens and Commercial Breeders in Diverse Regions in Brazil from July 1997 to December 2004

\section{DISCUSSION}

The present study showed that SE was the serovar most frequently isolated from breeders and broiler chickens. Tavechio et al. (1996) reported an increase in SE isolation from non-human sources in the State of São Paulo, from $1.2 \%$ in 1991 to $64.9 \%$ in 1995 . Such increase has been noticed in eggshells, birds and environment samples. Tavechio et al. (2002) reported that SE comprised $32.7 \%$ of 4581 samples of Salmonella isolated from non-human sources between 1996 and 2000. From all samples, 21.7\% had been isolated from commercial birds. SE has also been identified as the most frequently isolated serovar from birds by Van Duijkeren et al. (2002) and Ferris et al. (2004). On the other hand, conflicting results have been reported. FSIS (2004) showed that among the serovars isolated from broiler carcasses between 1998 and 1999, SE was the ninth most common serovar. Previous studies reported SE isolation from $5.15 \%$ of bird samples, derived products and poultry environment (Roy et al., 2002), from $2.7 \%$ of commercial laying hen flocks (Poppe et al., 1991a) and from 3.1\% of commercial broiler flocks (Poppe et al., 1991b). In Brazil, SE outbreaks were reported after cases in Europe, United States and Japan (Tavechio et al., 1996, Fernandes et al., 2003), probably because grandparent birds have been imported from these countries (Zancan et al., 2000). The importance of the high frequency of SE lies in the fact that salmonellosis is one of the most problematic zoonosis to public health worldwide (Hofer et al., 1997). Since 1994, this serovar has been implicated most frequently in outbreaks and sporadic cases of foodborne diseases in humans (Berchieri Júnior, 2000; Fernandes et al., 2003). It is also one of the serovars included in the control regulations established by the Brazilian National Program for Poultry Health (Plano Nacional de Sanidade Avícola, Brasil, 1995). SH was the second most frequent serovar in the breeder flocks examined in the present study. According to CCDR (1998), SH was the serovar most frequently isolated from non-human sources in 1995, which were almost exclusively bird samples. Studies carried out in the USA during 1999 and 2000 by Ferris et al. (2004) showed that $22 \%$ of salmonellas isolated from animal sources were originated from birds. These authors reported an increase of $58 \%$ in $\mathrm{SH}$ isolation, so that $67 \%$ of these samples were of poultry origin. The identification of this serovar in the present study $(22.8 \%)$ was similar to the occurrence of $25.8 \%$ reported by Roy et al. (2002). SH was one of the most 
Kanashiro AMI, Stoppa GFZ, Cardoso ALSP, Tessari ENC, Castro AGM

Serovars of Salmonella spp Isolated from Broiler Chickens and Commercial Breeders in Diverse Regions in Brazil from July 1997 to December 2004 frequent serovars in broiler carcasses (FSIS, 2004). Nevertheless, no SH was recovered from broiler chicken samples in the present study. Hofer et al. (1997) ranked the serovars of Salmonella isolated from birds between 1962 and 1991 according to the occurrence. The "most frequent" category included SE, SH, S. Typhimurium (STM) and S. Infantis. The "common" but not "frequent" serovars were $S$. Mbandaka and $S$. Kentucky, whereas S. I 9,12:-:- was considered "accidental" or "rare". It is worth noting that the latter was the second most frequent serovar isolated from broilers $(10.2 \%)$ and the fourth in breeders in the present study. STM was a predominant serovar in bird flocks from diverse regions in Brazil from 1962 to 1991 (Hofer et al., 1997). High STM frequency has also been reported by CCDR (1998), Ferris et al. (2000), Van Duijkeren et al. (2002) and FSIS (2004). Nevertheless, the findings in the present study showed STM positivity only in $1.3 \%$ and $2.1 \%$ of breeders and broilers, respectively. The findings presented herein must be carefully interpreted. Although flocks from different regions in Brazil have been sampled, the present data do not represent nationwide data on poultry salmonellosis, but could be seen as an estimate of the Brazilian scenario. Therefore, information about different Salmonella serovars on an incidence/ prevalence basis have been provided, which makes it possible to compare their frequencies among regions and track the predominant isolates in order to implement preventive or control measures (Hofer, 1985).

\section{CONCLUSION}

In conclusion, considering the sampling performed in the present study, $S$. Enteritidis was the serovar with the greatest occurrence among breeders and broiler chickens, predominating in percentages as high as $57.5 \%$ and $84.0 \%$, respectively.

\section{REFERENCES}

Barrow PA. Salmonella em Avicultura - Problemas e Novas Idéias sobre Possibilidades de Controle. Revista Brasileira de Ciência Avícola 1999; 1:9-16.

Berchieri Júnior A. Salmoneloses Aviárias. In: Berchieri Júnior A, Macari M, editores. Doenças das aves. Campinas: Facta; 2000. p. 185-96.

Brasil. Portaria $n^{\circ}$ 126, de 03 de novembro de 1995. Normas para credenciamento e monitoramento de laboratórios de diagnóstico das salmonelas aviárias. Diário Oficial da República Federativa do
Brasil, Poder Executivo, Brasília, DF, 06 nov. 1995. Seção I, p.176948.

Canadian Communicable Disease Report. Canadian integrated surveillance report for 1995 on Salmonella, Campylobacter and pathogenic Escherichia coli; 1998. v.24S5. [accessed jul. 26, 2004]. Available from: URL: http://www.hc-sc.gc.ca/pphb-dgspsp/publicat/ ccdr-rmtc/98vol24/24s5/24s5be.html

Fernandes AS, Ghilardi ACR., Tavechio AT, Machado AMO, Pignatari ACC. Phenotypic and molecular characterization of Salmonella enteritidis strains isolated in São Paulo, Brazil. Revista Instituto Medicina Tropical 2003; 45 (2):59-63.

Ferris KE, Flugrad BR, Timm JM, Ticer AE. Salmonella serotypes from animals and related sources reported during July 1999 June 2000. [acessed jul. 16, 2004]. Available from: URL: www.usaha.org/ speeches00/s00ferri.htm.

FSIS. Salmonella serotypes isolated from raw meat and poultry. U.S. Department of Agriculture Food Safety and Inspection Service. [acessed jul. 15, 2004]. Available: URL: http://www.fsis.usda.gov/ OPHS/haccp/sero1yr.htm.

Hofer E. Epidemiologia das salmoneloses: incidência de sorotipos de Salmonella em aves e rações (matérias-primas) no período de 1966-1984. In: $4^{\circ}$ SIMPÓSIO DO CENTRO NACIONAL DE PESQUISA DE SUÍNOS E AVES; 1985; Chapecó, Santa Catarina, Brasil. p.11024.

Hofer E, Silva Filho SJ, Reis EMF. Prevalência de sorovares de Salmonella isolados de aves no Brasil. Pesquisa Veterinária Brasileira 1997; 17(2):55-62.

Nepomuceno ES. Mitos e Realidade no Controle de Salmonella Enteritidis em Matrizes. In: Simpósio Internacional sobre Manejo de Matrizes e Incubação; 1997; Campinas. p.73-86.

Poppe C, Irwin RJ, Forsberg CM, Clarke RC, Oggel J. The prevalence of Salmonella enteritidis and other Salmonella spp. among Canadian registered commercial layer flocks. Epidemiology and Infection 1991; 106(2):259-70a.

Poppe C, Irwin RJ, Messier S, Finley GG, Oggel J. The prevalence of Salmonella enteritidis and other Salmonella sp. among Canadian registered commercial chicken broiler flocks. Epidemiology and Infection 1991; 107(1):201-11b.

Roy P, Dhillon AS, Lauerman LH, Schaberg DM, Bandli D, Johnson $S$. Results of Salmonella isolation from poultry products, poultry, poultry environment, and other characteristics. Avian Diseases 2002; 46 (1):17-24.

Tavechio AT, Fernandes SA, Neves BC, Dias AM, Irino K. Changing patterns of Salmonella serovars. increase of Salmonella enteritidis in São Paulo, Brazil. Revista Instituto de Medicina Tropical 1996; 38 (5): 315-22.

Tavechio AT, Ghilardi AC, Peresi JT, Fuzihara TO, Yonamine EK, Jakabi M, Fernandes SA. Salmonella serotypes isolated from nonhuman sources in São Paulo, Brazil, from 1996 through 2000. Journal of Food Protection 2002; 65 (6):1041-4. 
Kanashiro AMI, Stoppa GFZ, Cardoso ALSP, Tessari ENC, Castro AGM
Serovars of Salmonella spp Isolated from Broiler Chickens and Commercial Breeders in Diverse Regions in Brazil from July 1997 to December 2004

Van Duijkeren E, Wannet WJ, Houwers DJ, Van Pelt W. Serotypes and phage type distribution of salmonella strains isolated from humans, cattle, pigs, and chickens in the Netherlands from 1984 to 2001. Journal of Clinical Microbiology 2002; 40(11):3980-5.

Zancan FT, Berchieri Junior A, Fernandes SA, Gama NMSQ. Salmonella spp investigation in transport boxes of day-old birds. Brazilian Journal of Microbiology 2000; 31:230-2. 